\title{
Efikasi Diri Kesehatan Mental sebagai Mediator antara Dukungan Suami dengan Kelekatan Ibu-Janin
}

\author{
SULISTAMI PRIHANDINI* \& LINDA PRIMANA \\ Departemen Psikologi Pendidikan, Fakultas Psikologi Universitas Indonesia
}

\begin{abstract}
ABSTRAK
Dukungan sosial khususnya dukungan suami berkontribusi positif terhadap kelekatan ibu-janin (maternal fetal attachment (MFA)), namun hubungan tersebut masih inkonsisten. Kehamilan merupakan proses alamiah yang dapat menjadi sumber stres bagi calon ibu. Efikasi diri kesehatan mental (mental health self-efficacy (MHSE)) terbukti menurunkan depresi dan kecemasan, tidak terkecuali pada ibu hamil. Oleh karena itu, penelitian ini hendak melihat hubungan antara dukungan suami dan efikasi diri kesehatan mental terhadap kelekatan ibu-janin sekaligus melihat peran mediasi efikasi diri kesehatan mental atas hubungan dukungan suami dan kelekatan ibu-janin. Penelitian dilakukan dengan menggunakan kuisioner terhadap 281 ibu hamil di wilayah Jakarta, Depok, Bogor, Tangerang, Bekasi (Jadebotabek), khususnya wilayah Depok. Hasil analisis regresi sederhana menunjukkan adanya kontribusi yang signifikan dari dukungan suami dan efikasi diri kesehatan mental terhadap kelekatan ibu-janin. Hal ini berarti meningkatnya dukungan suami dan efikasi diri kesehatan mental dapat meningkatkan kelekatan ibu-janin. Hasil analisis model mediasi menggunakan menunjukkan bahwa efikasi diri kesehatan mental tidak memiliki peran sebagai mediator dalam hubungan antara dukungan suami dan kelekatan ibu-janin. Pada penelitian efikasi diri kesehatan mental hanya berperan sebagai variabel bebas yang berkontribusi terhadap kelekatan ibu-janin.
\end{abstract}

Kata kunci: dukungan sosial, dukungan suami, efikasi diri kesehatan mental, ibu hamil, kelekatan ibu dan janin

\begin{abstract}
Social support, especially husband support, contributes positively to maternal fetal attachment (MFA), but the relationship is still inconsistent. Pregnancy is a natural process that can be a source of stress for expectant mothers. Mental health self-efficacy (MHSE) has been shown to reduce depression and anxiety, including pregnant women. Therefore, this study wants to look at the relationship between husband support and MHSE on maternal fetal attachment as well as looking at the role of MHSE mediation over the relationship of husband support and MFA. The study was conducted using a questionnaire of 281 pregnant women in the Jakarta, Depok, Bogor, Tangerang, Bekasi (Jadebotabek) area, especially the Depok area. The results of the simple regression analysis showed a significant contribution from husband and MHSE support for MFA. This means that increased husband support and MHSE can increase MFA. The results of the analysis showed that MHSE did not have a role as a mediator in the relationship between husband support and MFA.
\end{abstract}

Keywords: husband support, maternal-fetal attachment, mental health self-efficacy, pregnancy, social support 
INSAN Jurnal Psikologi dan Kesehatan Mental, 2020, Vol. 5(2), 112-124, doi: 10.20473/jpkm.v5i22020.112-124 Dikirimkan: 17 Desember 2019 Diterima: 23 Maret 2020 Diterbitkan: 2 November 2020 Editor: Tri Kurniati Ambarini

*Alamat korespondensi: Jl. Rasamala Raya No.20 Depok Timur 16418 Pos-el: sulistami.prihandini@ui.ac.id

Naskah ini merupakan naskah dengan akses terbuka dibawah ketentuan the Creative Common Attribution License (http://creativecommons.org/licenses/by-sa/4.0), sehingga penggunaan, distribusi, reproduksi dalam media apapun atas artikel ini tidak dibatasi, selama sumber aslinya disitir dengan baik.

\section{PENDAH U L UA N}

Berdasarkan Survei Demografi dan Kesehatan Indonesia (SDKI) tahun 2012, angka kematian ibu di Indonesia sebesar 359 per 100.000 kelahiran (Kementerian Kesehatan RI, 2014). Tinjauan literatur yang dilakukan oleh Mgawadere, Kana, dan van den Broek (2017) mengenai angka kematian ibu di 60 negara berpenghasilan rendah dan menengah, diantaranya seperti Cina, Republik Dominika, Brazil, Mesir, Nigeria, Kamerun, Malawi, Zambia, India, Pakistan, dan Turki, menunjukkan angka rata-rata 519 per 100.000 kelahiran hidup. World Health Organization (WHO) menargetkan pada tahun 2030, tidak satu negarapun yang angka kematian ibu hamil dan melahirkan di atas 70 per 100.000 kelahiran (Mgawadere dkk., 2017). Ditinjau dari target WHO untuk tahun 2030, kondisi angka kematian ibu untuk Indonesia dan negara-negara berpenghasilan rendah dan menengah masih tinggi. Di Indonesia, Jawa Barat termasuk penyumbang angka kematian ibu nomor satu (Erviana, 2014).

Menurut penelitian Pratitis (2013) di Klaten, kemauan ibu dalam mencari informasi mengenai kesehatan kehamilannya merupakan hal penting dalam menurunkan tingginya angka kematian ibu hamil dan melahirkan. Selain perhatian terhadap kesehatan fisik, perlu diperhatikan faktor psikologi atau mental yang dapat memengaruhi kesehatan ibu hamil. Kondisi kesehatan mental yang tidak sehat dapat memengaruhi kondisi fisik ibu ketika hamil dan melahirkan (Maimunah \& Retnowati, 2011). Oleh karena itu, kesehatan mental dan fisik selama kehamilan merupakan faktor penting yang harus diperhatikan, khususnya dalam menghadapi tingginya Angka Kematian Ibu hamil dan melahirkan.

Terdapat faktor-faktor yang dapat memengaruhi kesehatan mental ibu hamil yang akan memengaruhi kesehatan fisiknya, diantaranya yaitu kelekatan antara ibu hamil dan janin dalam kandungan. Berdasarkan penelitian sebelumnya, ditemukan bahwa kelekatan antara ibu hamil dan janin ditemukan berkorelasi dengan kesadaran ibu mengenai praktik kesehatan terkait kehamilan, seperti kemauan menerima perawatan selama kehamilan dan kesadaran dalam mematuhi perawatan kehamilan yang disarankan serta mengurangi konsumsi alkohol selama kehamilan (Golbasi dkk., 2015). Hal ini sejalan dengan penelitian Pratitis (2013) yang menunjukkan bahwa pemeriksaan kehamilan rutin merupakan hal penting yang dapat menurunkan tingginya angka kematian ibu. Oleh karenanya, penelitian Golbasi, Ucar, dan Tugut (2015) tersebut membuktikan bahwa kelekatan antara ibu hamil dan janin dalam kandungan (maternal fetal attachment (MFA)) juga berperan penting terhadap kesehatan kehamilan ibu (Facello, 2008). Hal ini karena, ketika tingkat kelekatan ibu-janin seorang ibu hamil tinggi, maka ia akan lebih peduli pada kesehatannya, serta memiliki motivasi lebih untuk menjaga dan merawat kandungan dengan melakukan pemeriksaan rutin serta mencari informasi mengenai kesehatan kehamilannya (Golbasi, dkk., 2015)

Selain kelekatan ibu-janin, faktor lainnya yang juga memengaruhi kesehatan mental ibu selama kehamilan adalah dukungan sosial khususnya dukungan dari suami atau pasangan (Diniz, dkk., 2014). Sayangnya, penelitian mengenai ibu hamil di Indonesia masih menunjukkan kurangnya dukungan suami terhadap ibu hamil. Hal ini ditunjukkan dengan data sebesar $60 \%$ ibu yang tidak melakukan INSAN Jurnal Psikologi dan Kesehatan Mental 2020, Vol. 5(2), 112-124 
antenatal care secara teratur, tidak mendapatkan dukungan dari suami (Evayanti, 2015). Dukungan terhadap ibu hamil dapat diberikan oleh suami, keluarga dekat, keluarga besar, teman atau tetangga maupun komunitas setempat. Namun berdasarkan penelitian sebelumnya, ditemukan bahwa wanita hamil mendapat dukungan tertinggi dari suami mereka (Aktas \& Calik, 2015).

Penelitian ini hendak meneliti lebih lanjut hubungan dukungan suami terhadap kelekatan ibu-janin karena berdasarkan penelitian terbaru, prediktor dukungan suami secara signifikan meningkatkan kelekatan ibu-janin (Hopkins, dkk., 2018). Hanya saja dalam penelitian lain disebutkan bahwa dukungan suami ditemukan tidak berpengaruh secara signifikan (Maas, dkk., 2014). Meskipun hubungan antara dukungan suami dan kelekatan ibu-janin masih belum konsisten, namun dalam penelitian di Indonesia, dukungan suami dianggap faktor yang penting dalam memengaruhi kesehatan ibu hamil (Evayanti, 2015; Widodo, dkk., 2017).

Sebagian besar wanita hamil mengalami kecemasan dan stres dalam menghadapi gejala fisik dan perubahan biologis serta biokimia terkait kehamilan, kemungkinan perubahan hubungan pribadi dan keluarga, masalah sosial dan ekonomi, komplikasi medis dan obstetri terkait kehamilan, keselamatan bayi baru lahir dan tahap persalinan (Schetter, 2011). Stres mengacu pada situasi di mana kondisi internal dan eksternal melemahkan atau mengganggu fungsi normal energi dan jiwa manusia dan akibatnya merangsang sistem saraf otonom, khususnya sistem saraf simpatik, yang pada akhirnya menciptakan kecemasan pada individu (Navidpour, dkk., 2015). Kehamilan dan persalinan membentuk situasi stres khusus yang hanya dialami oleh wanita, yang membuat prevalensi kecemasan - komplikasi stres yang umum - dua kali lebih banyak pada wanita dibandingkan pada pria (Navidpour, dkk., 2015). Berbagai penelitian telah dilakukan di berbagai masyarakat untuk mengidentifikasi penyebab stres pada wanita hamil. Studi yang dilakukan pada prevalensi stres pada awal kehamilan di berbagai masyarakat menemukan bahwa 16,5-74 persen wanita menderita stres selama awal kehamilan mereka (Navidpour, dkk., 2015). Dengan demikian, stres dan kecemasan memengaruhi kelekatan ibu-janin secara negatif dimana stres dan kecemasan yang tinggi menurunkan kelekatan ibu hamil dan janin (Hopkins, dkk., 2018; Rusanen, dkk., 2018).

Kondisi stres dan kecemasan pada saat hamil, sebenarnya dapat diatasi jika seseorang memiliki efikasi diri kesehatan mental yang baik. Berdasarkan penelitian sebelumnya yang dilakukan oleh Clarke, dkk. (2014), efikasi diri kesehatan mental diyakini sebagai faktor yang efektif dalam menurunkan tingkat stres dan depresi yang berasal dari dalam diri seseorang. Oleh karena itu, dalam proses intervensi kesehatan mental, penting untuk memperhatikan peningkatan efikasi diri kesehatan mental dalam diri orang tersebut (Clarke, dkk., 2014).

Dalam penelitian yang dilakukan oleh Jex, Bliese, Buzzell, dan Primeau (2001), efikasi diri dapat mengurangi ketegangan atau stres seseorang hanya jika orang tersebut memiliki strategi koping aktif yang tinggi. Hal ini berarti, efikasi diri akan membantu seseorang dalam mengurangi stresnya hanya jika orang tersebut secara aktif melakukan sesuatu untuk mengelola kesehatan mentalnya sendiri. Berdasarkan hal tersebut, kemampuan untuk mengelola kesehatan mental pribadi merupakan hal yang penting. Oleh karenanya, efikasi diri seseorang dalam kemampuannya mengelola kesehatan mental, merupakan hal yang penting dalam mengatasi keadaan stres atau depresi yang dialaminya.

Pada teori sosio-kognitif, Bandura (1994) mendefinisikan efikasi diri sebagai keyakinan yang dimiliki seseorang mengenai kemampuan dalam dirinya untuk menghasilkan kinerja yang telah ditetapkan dimana kinerja tersebut memengaruhi peristiwa dalam kehidupan sehari-harinya. Sejauh ini belum ditemukan penelitian antara efikasi diri kesehatan mental dengan kelekatan ibu-janin. Penelitian sebelumnya menunjukkan adanya hubungan antara efikasi diri kesehatan mental dengan keadaan kesehatan mental seseorang seperti depresi dan stres (Clarke, dkk., 2014). Kondisi kesehatan mental ibu hamil yang kurang baik seperti depresi dan stres, dapat menurunkan kelekatan ibu-janin (Hopkins, INSAN Jurnal Psikologi dan Kesehatan Mental 2020, Vol. 5(2), 112-124

doi: $0.20473 /$ jpkm.v5i22020.112-124 
dkk., 2018). Dengan demikian, dari hasil-hasil penelitian tersebut dapat diasumsikan efikasi diri kesehatan mental berasosiasi dengan kelekatan ibu-janin.

Efikasi diri pada penelitian-penelitian sebelumnya telah terbukti sebagai variabel mediator antara banyak variabel seperti stres dan kesehatan mental (Schönfeld, dkk., 2016), terapi psikologis dan kelelahan mental (Breukers, dkk., 2019), gaya kelekatan, dan resiliensi (Bender \& Ingram, 2018). Menurut Bandura (1977), kondisi emosi yang negatif dapat menurunkan efikasi diri. Di lain pihak, dukungan sosial membantu ibu hamil menjadi lebih positif secara emosional, serta mengalami pengalaman positif terkait kesehatan mental yang dimilikinya (Maas dkk., 2014). Selain itu, berdasarkan penelitian sebelumnya juga diketahui bahwa dukungan yang didapatkan ibu hamil dari suaminya dapat meningkatkan efikasi diri dan kesehatan mental ibu hamil tersebut (Ginja dkk., 2018). Dengan demikian, dukungan suami berhubungan dengan efikasi diri dan efikasi diri berasosiasi dengan kelekatan ibujanin.

Penelitian Zhang dan Jin (2016) yang meneliti tentang dukungan sosial dan depresi ibu pasca melahirkan, menunjukkan adanya peran efikasi diri ibu sebagai mediator terhadap hubungan dukungan sosial dan depresi. Selain itu, sebagian besar wanita yang baru melahirkan mungkin tidak mengetahui jawaban atas semua pertanyaan mereka, membutuhkan bantuan, dan memerlukan dukungan dalam menghadapi situasi yang penuh tekanan. Kurangnya dukungan di fase ini dapat menyebabkan rendahnya efikasi diri ibu pasca melahirkan yang pada akhirnya dapat menyebabkan munculnya depresi (Zhang \& Jin, 2016). Keadaan stres dan cemas, dapat dialami tidak hanya oleh ibu pasca melahirkan, namun juga oleh ibu hamil (Navidpour, dkk., 2015; Schetter, 2011). Dengan demikian, efikasi diri kesehatan mental ibu hamil diasumsikan memiliki peran sebagai mediator antara dukungan suami terhadap kelekatan ibu-janin.

Penelitian ini mengambil partisipan ibu hamil yang tinggal di Jadebotabek dari segala jenis status sosial ekonomi dan pada seluruh usia kehamilan. Penelitian dibatasi pada wilayah Jadebotabek karena masyarakat Jabodetabek terdiri dari berbagai etnis dan strata pendidikan. Wilayah ini juga merupakan merupakan pusat ibu kota dan sekitarnya yang memiliki akses informasi dan pendidikan paling baik dibandingkan dengan pulau lain serta kota-kota lain di Indonesia sehingga tingkat literasi media masyarakat Jakarta lebih baik daripada daerah lainnya di Indonesia (Harahap, 2017). Dengan akses informasi dan pendidikan serta tingkat literasi yang besar, besar kemungkinan populasi di wilayah ini telah terpapar mengenai informasi seputar kehamilan, termasuk mengenai pentingnya dukungan suami, pemeriksaan rutin serta kelekatan ibu hamil dan janin selama proses kehamilan. Sebagaimana telah dijelaskan sebelumnya, Jawa Barat merupakan penyumbang angka kematian ibu nomor satu di Indonesia (Erviana, 2014). Oleh karena itu, penelitian ini hendak melihat kontribusi dukungan suami dalam memengaruhi kelekatan ibu hamil dan janin serta peran mediasi dari efikasi diri kesehatan mental pada ibu hamil di wilayah Depok dan Bogor yang merupakan bagian dari wilayah Jawa Barat namun berbatasan langsung dengan Jakarta. Selain di Depok dan Bogor, penelitian ini juga mengambil sebagian kecil sampel di wilayah Jakarta, Tangerang, dan Bekasi yang merupakan pusat ibu kota. 


\section{ME T O D E}

\section{Desain Penelitian}

Penelitian ini merupakan penelitian berjenis kuantitatif, yang menggunakan skala berbentuk self-report sebagai alat pengumpul data. Populasi dari penelitian ini adalah ibu hamil di Jakarta, Depok, Bogor, Tangerang, dan Bekasi (Jabodetabek). Teknik perekrutan partisipan dilakukan dengan metode nonprobability sampling, dimana banyaknya populasi tidak diketahui dan tidak semua individu dalam populasi berkesempatan untuk menjadi sampel penelitian (Gravetter \& Forzano, 2012). Selain itu, teknik pengambilan sampel dilakukan dengan teknik convenience sampling, dimana peneliti mencari partisipan penelitian yang cenderung mudah didapat dan bersedia menjadi partisipan (Gravetter \& Forzano, 2012). Pengumpulan data dilakukan di Puskesmas dan Rumah Sakit di Jadebotabek.

Penelitian ini bertujuan untuk menjawab pertanyaan apakah dukungan suami berkontribusi secara signifikan terhadap mental health self-efficacy, apakah dukungan suami berkontribusi secara signifikan terhadap maternal fetal attachment, apakah mental health self-efficacy berkontribusi secara signifikan terhadap maternal fetal attachment, dan apakah mental health self-efficacy memediasi hubungan dukungan suami terhadap kelekatan ibu terhadap janin (maternal fetal attachment).

\section{Pengukuran}

Penelitian ini mengukur dukungan suami dengan mengadaptasi alat ukur Skala Dukungan Suami yang dibuat oleh Rahmawati (2015) dalam Bahasa Indonesia. Pernyataan disusun untuk menggambarkan dukungan suami pada ibu hamil. Skala Dukungan Suami terdiri dari dimensi bentuk dukungan emosional, dukungan informasi, dukungan instrumental, dan dukungan penghargaan. Pernyataan berjumlah 48 buah terdiri dari 36 pernyataan positif dan 12 pernyataan negatif yang disusun dalam Skala Likert (1-4). Skor yang lebih tinggi menunjukkan dukungan suami yang lebih tinggi (Rahmawati, 2015).

Validitas dan reliabilitas alat ukur Skala Dukungan Suami, diuji coba terhadap 30 orang ibu hamil. Dari hasil uji coba tersebut, diperoleh nilai Cronbach's Alpha sebesar 0,939, dengan menetapkan batas minimum validitas item $\left(r_{\mathrm{it}} \geq 0,2\right)$ (Aiken, 1985). Berdasarkan hasil uji coba, terdapat tiga item yang memiliki skor $r_{\text {it }}<0,2$. Meski demikian, peneliti memutuskan tetap menggunakan ketiga item tersebut karena skornya masih mendekati 0,2 .

MFA diukur dengan menggunakan alat ukur Maternal Fetal Attachment Scale (MFAS) yang dibuat oleh Cranley (1981) yang telah diadaptasi. MFAS mengukur lima variabel yaitu diferensiasi diri dari janin (differentiation of selffrom the fetus), interaksi dengan janin (interaction with the fetus), menghubungkan karakteristik dan niat untuk janin (attributing characteristics and intentions to the fetus), memberi diri (giving of self), dan pengambilan peran (role taking). MFAS menggunakan 5-poin skala Likert (1='tidak sama sekali' hingga 5='sudah pasti') dimana skor yang lebih tinggi menunjukkan tingkat MFA yang lebih tinggi (Cranley, 1981).

Uji coba validitas dan reliabilitas MFAS yang telah diadaptasi dilakukan terhadap 30 orang partisipan. Dari hasil pengukuran, didapatkan nilai Cronbach's Alpha sebesar 0,815. Dari 24 aitem teruji, terdapat dua aitem yang memiliki skor $r_{\text {it }}<0,2$. Berdasarkan hasil tersebut, peneliti memutuskan untuk menghapus dan tidak mengikutsertakan dua aitem tersebut dalam pengolahan data.

Variabel MHSE dalam penelitian ini diukur dengan mengadaptasi alat ukur yang dibuat oleh Clarke dkk. (2014). Alat ukur ini memiliki 6 item pertanyaan yang dibuat dengan menggunakan panduan pembuatan alat ukur self-efficacy dari Bandura (Bandura, 1977).

INSAN Jurnal Psikologi dan Kesehatan Mental

2020, Vol. 5(2), 112-124

doi: $0.20473 /$ jpkm.v5i22020.112-124 
Berdasarkan hasil focus group discussion (FGD) tentang kesehatan mental dengan ibu hamil sebagai partisipan, alat ukur ditambahkan dua item, sehingga total alat ukur MHSE pada penelitian ini berjumlah 8 item. FGD perlu dilakukan lantaran perbedaan peruntukan alat ukur. Alat ukur MHSE semula digunakan terhadap pasien kesehatan mental dan bukan terhadap ibu hamil. Oleh karena itu, diperlukan penyesuaian alat ukur terhadap konteks kesehatan mental ibu hamil. FGD dilakukan terhadap enam orang ibu hamil dan dua orang bidan yang berpengalaman dalam membantu kelahiran. Pada FGD ini dibahas mengenai hal-hal apa saja yang memengaruhi kesehatan mental ibu hamil. Hasilnya, terdapat hal khusus yang dapat memicu stres ibu hamil, yaitu opini negatif dari orang di sekitar ibu hamil terkait dengan kehamilannya.

Setiap pernyataan dijabarkan dalam skala 1-10, dimana 1 mewakili kondisi tidak percaya diri sama sekali (not at all confident), sementara 10 mewakili kondisi sangat percaya diri (totally confident). Skor yang lebih tinggi menunjukkan MHSE yang lebih tinggi. Alat ukur ini bersifat unidimensional. Peneliti menggunakan skor mean dari keseluruhan item.

Peneliti melakukan uji coba validitas dan reliabilitas atas alat ukur Mental Health Self-Efficacy Scale (MHSES) yang telah diadaptasi terhadap 30 orang ibu hamil. Hasil Cronbach's Alpha sebesar 0,913. Hasil uji coba alat ukur MHSES menunjukkan skor $r_{\text {it }}>0,2$ untuk seluruh item. Oleh karena itu, peneliti menggunakan keseluruhan item dalam pengambilan data yang sebenarnya.

\section{Analisis Data}

Untuk menguji hipotesis penelitian, yaitu efikasi diri kesehatan mental memperantarai hubungan antara dukungan suami dengan kelekatan ibu-janin, penulis melakukan analisis bootstrapped mediated regression dengan 5000 iterations dengan bantuan perangkat lunak IBM SPSS versi 23 dan macro PROCESS versi 3.0 (Hayes, 2017).

\section{HAS I L P E NELIT I A N}

Partisipan dalam penelitian ini sebanyak 281 ibu hamil yang berdomisili di wilayah Jadebotabek. Data diambil secara online dan offline. Untuk data offline, peneliti mengambil data di rumah sakit dan Puskesmas kota Depok. Berikut gambaran persebaran partisipan berdasarkan lokasi pengambilan data:

Tabel 1. Jumlah Persebaran Pengambilan Data $(N=281)$

\begin{tabular}{lcc}
\hline \multicolumn{1}{c}{ Sumber pengambilan data } & Jumlah Partisipan & Persentase \\
\hline Online & 98 & $34.9 \%$ \\
Puskesmas & 118 & $42.0 \%$ \\
Rumah Sakit & 56 & $19.9 \%$ \\
Lain-Lain (teman, kenalan, dsb) & 9 & $3.2 \%$ \\
\hline
\end{tabular}

Sebagian besar partisipan dalam penelitian ini adalah ibu hamil yang ditemui peneliti di puskesmas (42 persen). Pengambilan data berikutnya berasal dari kuesioner yang disebat secara online oleh peneliti (34,9 persen), disusul data dari ibu hamil yang ada di rumah sakit (19,9 persen).

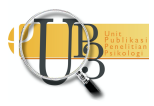


Tabel 2. Jumlah Persebaran Kota Partisipan ( $N=281)$

\begin{tabular}{lcc}
\hline \multicolumn{1}{c}{ Kota } & Jumlah Partisipan & Persentase \\
\hline Jakarta & 47 & $16,7 \%$ \\
Depok & 189 & $67,3 \%$ \\
Bogor & 19 & $6,8 \%$ \\
Tangerang & 11 & $3,9 \%$ \\
Bekasi & 15 & $5,3 \%$ \\
\hline
\end{tabular}

Perolehan data berasal dari lima kota, yaitu Jakarta, Depok, Bogor, Tangerang, dan Bekasi. Data dalam penelitian ini didominasi oleh ibu hamil yang berasal dari kota Depok sebanyak 67,3 persen, disusul oleh kota Jakarta sebesar 16,7 persen. Sementara itu, penyebaran data partisipan berdasarkan data diri dalam penelitian ini digambarkan dalam tabel berikut:

Tabel 3. Gambaran Penyebaran Partisipan berdasarkan Data Diri $(N=281)$

\begin{tabular}{cccc}
\hline & Kategori & Jumlah Partisipan & Persentase \\
\hline \multirow{4}{*}{ Usia Partisipan } & $10-20$ Tahun & 7 & $2,5 \%$ \\
& $21-30$ Tahun & 181 & $64,4 \%$ \\
& $31-40$ Tahun & 90 & $32,0 \%$ \\
\hline Tingkat Penghasilan & 41-50 Tahun & 3 & $1,1 \%$ \\
& Rp.0 - Rp. 2.000.000 & 23 & $8,2 \%$ \\
& Rp.2.000.000 - Rp.4.000.000 & 73 & $26 \%$ \\
& Rp.4.000.000 - Rp.8.000.000 & 87 & $31 \%$ \\
& Rp.8.000.000 - Rp.15.000.000 & 64 & $22,8 \%$ \\
& $>$ Rp.15.000.000 & 34 & $12,1 \%$ \\
\hline \multirow{5}{*}{ Tingkat Pendidikan } & SD & 3 & $1,1 \%$ \\
& SMP & 15 & $5,3 \%$ \\
& SMA/ SMK/ D1/D2 & 102 & $36,3 \%$ \\
& D3 & 23 & $8,2 \%$ \\
& S1 & 125 & $44,5 \%$ \\
& S2/ Profesi & 13 & $4,6 \%$ \\
\hline Jumlah Anak & 0 & 115 & $41,3 \%$ \\
Sebelumnya & 1 & 114 & $40,6 \%$ \\
& 2 & 37 & $13,2 \%$ \\
& 3 & 12 & $4,3 \%$ \\
& $>4$ & 2 & $0,8 \%$ \\
\hline & $10-20$ Tahun & 1 & $0,4 \%$ \\
& $21-30$ Tahun & 140 & $49,8 \%$ \\
& $31-40$ Tahun & 123 & $43,8 \%$ \\
& $41-50$ Tahun & 15 & $5,3 \%$ \\
& $51-60$ Tahun & 2 & $0,7 \%$ \\
\hline
\end{tabular}

Berdasarkan data di Tabel 3, dapat dilihat bahwa usia terbanyak dari partisipan penelitian ini berada pada rentang 21-30 tahun disusul rentang usia 31-40 tahun. Usia ini berada pada tahap perkembangan dewasa muda dan dewasa madya. Tingkat penghasilan terbanyak dari partisipan berada antara Rp.4.000.000 - Rp.8.000.000, yaitu berada pada batas rata-rata Upah Minimum Regional (UMR) hingga

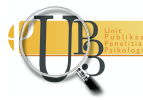


dua kali batas rata-rata UMR. Tingkat penghasilan terbanyak berikutnya berada pada setengah batas rata-rata UMR hingga rata-rata UMR.

Pada partisipan ibu hamil di wilayah Jadebotabek ini, kebanyakan partisipan memiliki tingkat pendidikan terakhir S1 disusul dengan tingkat pendidikan terakhir SMA/SMK/D1/D2. Untuk jumlah anak yang telah dimiliki sebelumnya, partisipan terbanyak adalah yang belum memiliki anak sebelumnya. Partisipan terbanyak berikutnya telah memiliki 1 anak sebelumnya. Usia terbanyak dari suami partisipan penelitian ini berada pada rentang 21-30 tahun disusul dengan rentang usia suami antara 31-40 tahun. Hal ini sama dengan persebaran rentang usia terbanyak dari partisipan ibu hamil.

Berdasarkan kondisi kehamilan partisipan, penyebaran data dalam penelitian ini digambarkan dalam tabel berikut:

Tabel 4. Gambaran Kehamilan Partisipan $(N=281)$

\begin{tabular}{clcc}
\hline & \multicolumn{1}{c}{ Kategori } & $\begin{array}{c}\text { Jumlah } \\
\text { Partisipan }\end{array}$ & Persentase \\
\hline \multirow{2}{*}{ Rencana Kehamilan } & Kehamilan tidak direncanakan & 87 & $31 \%$ \\
& Kehamilan direncanakan & 194 & $69 \%$ \\
\hline \multirow{3}{*}{ Usia Kehamilan } & Trimester 1 & 46 & $16,4 \%$ \\
& Trimester 2 & 78 & $27,8 \%$ \\
& Trimester 3 & 157 & $55,9 \%$ \\
\hline \multirow{5}{*}{ Urutan Kehamilan } & Kehamilan ke 1 & 111 & $39,5 \%$ \\
& Kehamilan ke 2 & 115 & $40,9 \%$ \\
& Kehamilan ke 3 & 36 & $12,8 \%$ \\
& Kehamilan ke 4 & 14 & $5 \%$ \\
& Kehamilan ke 5 & 3 & $1,1 \%$ \\
& Kehamilan ke 6 & 1 & $0,4 \%$ \\
& Kehamilan ke 7 & 1 & $0,4 \%$ \\
\hline
\end{tabular}

Lebih dari setengah jumlah partisipan memiliki kehamilan yang direncanakan, sedangkan sebagian kecil lainnya memiliki kehamilan yang tidak direncanakan. Partisipan ibu hamil terbanyak berada pada trimester ketiga kehamilan. Dapat dilihat juga bahwa partisipan ibu hamil terbanyak berada pada kehamilan kedua.

Berdasarkan hasil uji korelasi yang dilakukan peneliti, korelasi antara dukungan suami dengan efikasi diri kesehatan mental adalah sedang $(r(281)=0.195, p=0.001)$. Oleh karena itu, hipotesis 1 penelitian, yaitu terdapat korelasi antara dukungan suami terhadap efikasi diri kesehatan mental diterima. Selain itu, hasil korelasi dukungan suami terhadap kelekatan ibu-janin adalah sedang $(r(281)=0.290, p=0.000)$ dan korelasi antara efikasi diri kesehatan mental terhadap kelekatan ibu-janin sebesar adalah lemah $(r(281)=0.130, p=0.029)$.

Oleh karena itu dapat disimpulkan bahwa kedua variabel tersebut berhubungan secara positif terhadap kelekatan ibu-janin. Dengan kata lain, dukungan suami dan efikasi diri kesehatan mental ibu hamil berkorelasi dengan kelekatan hubungan antara dirinya dengan janin dalam kandungannya. Oleh karena itu, hipotesis 2 penelitian, yaitu terdapat korelasi yang signifikan dari dukungan suami terhadap kelekatan ibu terhadap janin, serta hipotesis 3 penelitian, yaitu terdapat korelasi yang signifikan dari efikasi diri kesehatan mental terhadap kelekatan ibu terhadap janin, diterima.

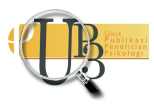


Dari hasil analisis mediated regression $\left(F(2,278)=13.716, p=0.000, R^{2}=0.898\right)$, terlihat bahwa efikasi diri kesehatan mental $(B=0,026, S E=0.203, t=1,307, p=0.192)$ berkontribusi positif namun tidak signifikan dalam menjelaskan kelekatan ibu-janin. Hal tersebut menunjukkan bahwa ketika bersama-sama dengan variabel dukungan suami, efikasi diri kesehatan mental menjadi tidak signifikan dalam mempengaruhi kelekatan ibu-janin. Setelah dimasukkan variabel mediator efikasi diri kesehatan mental $(F(2$, 278)=13.716, $p=0.000, R^{2}=0.898$ ), nilai $p$ hubungan antara variabel independen dukungan suami terhadap variabel dependen kelekatan ibu-janin tetap signifikan. Berdasarkan hal tersebut, diketahui bahwa efikasi diri kesehatan mental tidak memediasi hubungan antara dukungan suami terhadap kelekatan ibu-janin.

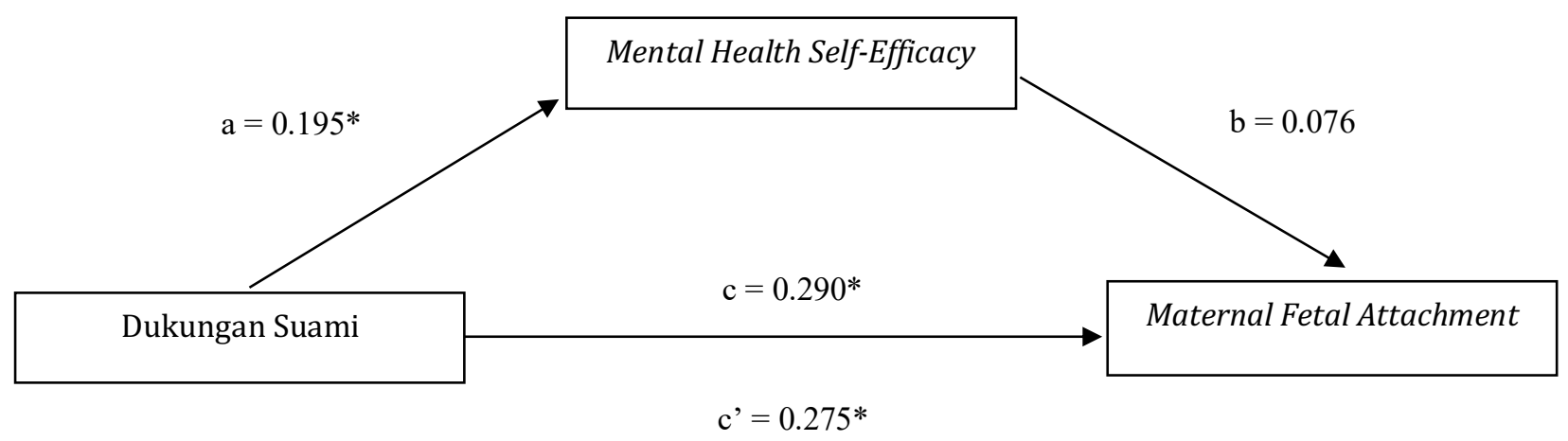

Gambar 1. Koefisien Jalur Estimasi Antar Variabel Penelitian

Pada gambar di atas, terlihat bahwa terdapat pengaruh yang signifikan dari variabel dukungan suami terhadap variabel kelekatan ibu-janin. Semakin tinggi dukungan yang diberikan suami pada istrinya yang hamil $(B=0,026, S E=, t=1,307, p=0.000)$, maka kelekatan ibu hamil dengan janinnya akan semakin tinggi. Dukungan suami $(B=0,026, S E=, t=1,307, p=0.001)$ juga berpengaruh secara signifikan terhadap efikasi diri kesehatan mental, namun efikasi diri kesehatan mental tidak memediasi pengaruh dari dukungan suami terhadap kelekatan ibu-janin karena hubungan dukungan suami terhadap kelekatan ibu-janin secara langsung memiliki koefisien yang lebih besar dibandingkan dengan ketika dimediasi oleh efikasi diri kesehatan mental $(B=0,026, S E=, t=1,307, p=0.192)$.

Dengan kata lain, dukungan suami memengaruhi kelekatan ibu-janin secara langsung tanpa melalui efikasi diri kesehatan mental. Oleh karena itu, hipotesis 4 penelitian yang menyatakan bahwa terdapat peran mediator efikasi diri kesehatan mental dalam hubungan dukungan suami terhadap kelekatan ibu dan janin ditolak.

\section{I S K U S I}

Berdasarkan hasil penelitian ini, variabel dukungan suami, variabel efikasi diri kesehatan mental berhubungan secara signifikan dan positif terhadap kelekatan ibu-janin. Dengan kata lain, dukungan suami dan keyakinan ibu hamil akan kemampuannya dalam mengelola kesehatan mentalnya, dapat mempengaruhi kelekatan hubungan antara dirinya dengan janin dalam kandungannya. Semakin tinggi dukungan suami dan efikasi diri kesehatan mental yang dimiliki ibu hamil, semakin meningkatkan kelekatan hubungan antara ibu hamil dan janin.

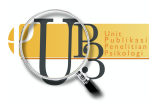


Hal ini sesuai dengan penelitian sebelumnya yang menunjukkan bahwa dukungan sosial secara langsung mempengaruhi kelekatan ibu-janin secara positif serta melemahkan pengaruh negatif depresi terhadap tingkat kelekatan ibu-janin (Hopkins, dkk., 2018), dan berdasarkan penelitian sebelumnya, ditemukan bahwa wanita hamil mendapat dukungan sosial tertinggi dari suami mereka (Aktas \& Calik, 2015).

Temuan lain dalam penelitian ini yang belum pernah dibahas dalam penelitian mengenai kelekatan ibujanin sebelumnya adalah adanya hubungan yang signifikan dan positif antara efikasi diri kesehatan mental dengan kelekatan ibu-janin, dimana dapat diartikan bahwa semakin tinggi keyakinan ibu hamil bahwa ia mampu mengelola kesehatan mentalnya sendiri, maka semakin tinggi kelekatan antara ibu hamil dan janin yang dikandungnya. Efikasi diri ibu hamil akan kemampuannya dalam mengelola kesehatan mentalnya sendiri menjadi penting, karena kehamilan memicu stres internal dan eksternal.

Sebagian besar wanita hamil mengalami kecemasan dan stres dalam menghadapi gejala fisik dan perubahan biologis dan biokimia kehamilan, kemungkinan perubahan hubungan pribadi dan keluarga, masalah sosial dan ekonomi, komplikasi medis dan obstetri terkait kehamilan, keselamatan bayi baru lahir dan tahap persalinan (Schetter, 2011). Berdasarkan penelitian sebelumnya, ditemukan bahwa efikasi diri kesehatan mental berhubungan signifikan secara negatif dengan stres dan depresi (Clarke, dkk., 2014). Dalam penelitian tersebut, efikasi diri kesehatan mental diyakini sebagai faktor yang efektif dalam menurunkan tingkat depresi yang berasal dari dalam diri seseorang. Oleh karenanya, efikasi diri kesehatan mental yang tinggi penting untuk dimiliki seorang wanita hamil, karena akan dapat berdampak positif terhadap hubungan kelekatan antara ia dan janinnya.

Dalam penelitian ini, meskipun persyaratan mediasi telah terpenuhi, dimana dukungan suami mempengaruhi efikasi diri kesehatan mental dan kelekatan ibu-janin secara signifikan, namun ketika dimasukkan secara bersama-sama, signifikansi pengaruh dukungan suami terhadap kelekatan ibu-janin tidak berkurang. Justru signifikansi pengaruh efikasi diri kesehatan mental terhadap kelekatan ibujanin yang melemah.

Tidak terjadinya mediasi oleh efikasi diri kesehatan mental antara hubungan variabel dukungan suami terhadap variabel kelekatan ibu-janin, menunjukkan bahwa meskipun dukungan suami secara signifikan berhubungan dengan efikasi diri kesehatan mental ibu hamil, namun kurangnya dukungan suami tidak serta merta menjadikan berkurangnya efikasi diri kesehatan mental ibu hamil yang kemudian menurunkan kelekatan hubungan ibu hamil dan janin, atau sebaliknya. Hal ini mungkin disebabkan karena efikasi diri kesehatan mental yang dimiliki ibu hamil tidak hanya terbentuk sejak pernikahan, namun terbentuk melalui proses seumur hidup. Oleh karenanya, efikasi diri kesehatan mental merupakan hal yang berbeda dari dukungan suami, yang juga turut mempengaruhi kelekatan ibu hamil terhadap janinnya.

Meski demikian, dukungan suami tetaplah merupakan hal yang penting bagi ibu hamil (Aktas \& Calik, 2015). Hal ini dapat dilihat dari hasil perhitungan regresi, dimana signifikansi efikasi diri kesehatan mental terhadap kelekatan ibu-janin berkurang ketika dilakukan model mediasi dengan variabel dukungan suami. Hal ini bisa jadi menunjukkan bahwa meskipun seorang ibu hamil memiliki keyakinan yang tinggi terhadap kemampuannya dalam mengelola kesehatan mental yang dapat meningkatkan kelekatannya terhadap janin, namun dukungan suami jauh lebih kuat dalam mempengaruhi kelekatan ibu hamil terhadap janin. Oleh karena itu, pentingnya dukungan suami terhadap kelekatan ibu hamil dan janin merupakan faktor penting yang tidak dapat diabaikan. Hanya saja, selain dukungan suami, seorang ibu hamil juga sangat penting untuk memiliki keyakinan yang kuat atas kemampuannya mengelola kesehatan mentalnya, karena hal tersebut akan mempengaruhi hubungannya dengan janinnya yang pada akhirnya akan mempengaruhi kesehatan kehamilannya. 


\section{S I M P U L A N}

Menjawab pertanyaan penelitian, dapat disimpulkan bahwa dukungan suami berkontribusi secara signifikan terhadap efikasi diri kesehatan mental. Efikasi diri kesehatan mental berkontribusi secara signifikan terhadap kelekatan ibu-janin. Dukungan suami berkontribusi secara signifikan terhadap kelekatan ibu-janin, namun tidak memediasi hubungan dukungan suami terhadap kelekatan ibu-janin.

Dengan kata lain, dukungan suami dan efikasi diri kesehatan mental ibu hamil, dapat memengaruhi kelekatan hubungan antara dirinya dengan janin dalam kandungannya. Semakin tinggi dukungan suami dan efikasi diri kesehatan mental yang dimiliki ibu hamil, semakin meningkatkan kelekatan hubungan antara ibu hamil dan janin. Melalui analisis mediasi, ditemukan bahwa efikasi diri kesehatan mental tidak memiliki peran sebagai mediator dalam hubungan dukungan suami dengan kelekatan ibu dan janin. Hal ini dapat diartikan bahwa dukungan suami yang diterima ibu hamil tidak mempengaruhi kelekatan melalui efikasi diri kesehatan mental.

Untuk alat ukur kelekatan ibu-janin, penelitian ini menggunakan alat ukur kelekatan ibu-janin yang dibuat pertama kali oleh Cranley (1981) dan terus digunakan hingga saat ini di berbagai negara. Dalam penelitian ini, alat ukur kelekatan ibu-janin memiliki nilai validitas yang baik kecuali untuk 2 aitem. Penelitian selanjutnya dapat melakukan perbaikan dalam proses adaptasi sehingga akan didapatkan nilai validitas yang lebih baik. Penelitian selanjutnya juga perlu memperhatikan keseimbangan dalam kontrol demografis partisipan serta memperluas cakupan wilayah penelitian.

\section{UCAPAN TERIMAKASIH}

Penulis mengucapkan terima kasih kepada pihak-pihak yang telah membantu tercapainya penelitian ini khususnya kepada para pengajar dan segenap sivitas akademik program studi Ilmu Psikologi Pendidikan Fakultas Psikologi Universitas Indonesia, staf dan bidan puskesmas serta rumah sakit tempat peneliti mengambil data penelitian, rekan-rekan Sains Pendidikan Universitas Indonesia 2017 dan 2018, seluruh partisipan penelitian, serta pihak-pihak lain yang terkait dalam proses penelitian dan mendukung selama proses pengambilan data.

\section{DEKLARASI POTENSI TERJADINYA KONFLIK KEPENTINGAN}

Sulistami Prihandini dan Linda Primana tidak bekerja, menjadi konsultan, memiliki saham, atau menerima dana dari perusahaan atau organisasi mana pun yang akan mengambil untung dari naskah ini, dan telah mengungkapkan bahwa ia tidak memiliki afiliasi selain yang telah disebut di atas.

\section{PUSTAKA ACUAN}

Aiken, L. R. (1985). Psychological testing and assessment (5th ed). Allyn and Bacon.

Aktas, S., \& Calik, K. Y. (2015). Factors affecting depression during pregnancy and the correlation between social support and pregnancy depression. Iranian Red Crescent Medical Journal, 17(9). https://doi.org/10.5812/ircmj.16640

Bandura, A. (1977). Self-efficacy: Toward a unifying theory of behavioral change. Psychological Review, 84(2), 191-215. https://doi.org/10.1037/0033-295X.84.2.191

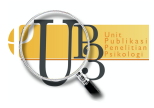


Bender, A., \& Ingram, R. (2018). Connecting attachment style to resilience: Contributions of self-care and self-efficacy. Personality and Individual Differences, 130, 18-20. https://doi.org/10.1016/j.paid.2018.03.038

Breukers, E. M. C., Raijmakers, R. P. H., Nieuwkerk, P. T., Bleijenberg, G., van der Meer, J. W. M., BleekerRovers, C. P., Keijmel, S. P., \& Knoop, H. (2019). Mediation analysis shows that a decline in selfefficacy mediates the increase in fatigue severity following an initial positive response to cognitive behavioural therapy in Q fever fatigue syndrome. Journal of Psychosomatic Research, 127, 109841. https://doi.org/10.1016/j.jpsychores.2019.109841

Clarke, J., Proudfoot, J., Birch, M.-R., Whitton, A. E., Parker, G., Manicavasagar, V., Harrison, V., Christensen, H., \& Hadzi-Pavlovic, D. (2014). Effects of mental health self-efficacy on outcomes of a mobile phone and web intervention for mild-to-moderate depression, anxiety and stress: Secondary analysis of a randomised controlled trial. BMC Psychiatry, 14(1), 272. https://doi.org/10.1186/s12888-014-0272-1

Cranley, M. S. (1981). Development of a tool for the measurement of maternal attachment during pregnancy. Nursing Research, 30(5), 281-284.

Diniz, E., Volling, B. L., \& Koller, S. H. (2014). Social support moderates association between depression and maternal-fetal attachment among pregnant Brazilian adolescents. Journal of Reproductive and Infant Psychology, 32(4), 400-411. https://doi.org/10.1080/02646838.2014.910865

Erviana, E. (2014, Desember). Angka kematian ibu tertinggi ada di Jawa Barat. Kompas.com. https://lifestyle.kompas.com/read/2014/12/05/074000923/Angka.Kematian.Ibu.Tertinggi.ada .di.Jawa.Barat

Evayanti, Y. (2015). Hubungan pengetahuan ibu dan dukungan suami pada ibu hamil terhadap keteraturan kunjungan antenatal care (ANC) di Puskesmas Wates Lampung Tengah tahun 2014. Jurnal Kebidanan, 1(2), 81-90.

Facello, D. C. (2008). Maternal/fetal attachment among family relationships, maternal health practices, and antenatal attachment [Dissertation]. West Virginia University.

Ginja, S., Coad, J., Bailey, E., Kendall, S., Goodenough, T., Nightingale, S., Smiddy, J., Day, C., Deave, T., \& Lingam, R. (2018). Associations between social support, mental wellbeing, self-efficacy and technology use in first-time antenatal women: Data from the BaBBLeS cohort study. BMC Pregnancy and Childbirth, 18(1), 441. https://doi.org/10.1186/s12884-018-2049-x

Golbasi, Z., Ucar, T., \& Tugut, N. (2015). Validity and reliability of the Turkish version of the Maternal Antenatal Attachment Scale: Validity and reliability of the MAAS. Japan Journal of Nursing Science, 12(2), 154-161. https://doi.org/10.1111/jjns.12052

Gravetter, F. J., \& Forzano, L.-A. B. (2012). Research methods for the behavioral sciences (4th ed). Wadsworth.

Harahap, H. (2017). Preferensi media masyarakat Jabodetabek dan faktor-faktor yang mempengaruhinya. Jurnal Studi Komunikasi dan Media, 21(1), 43-58.

Hopkins, J., Miller, J. L., Butler, K., Gibson, L., Hedrick, L., \& Boyle, D. A. (2018). The relation between social support, anxiety and distress symptoms and maternal fetal attachment. Journal of Reproductive and Infant Psychology, 36(4), 381-392. https://doi.org/10.1080/02646838.2018.1466385 
Kementerian Kesehatan RI. (2014). Infodatin mother's day: Situasi kesehatan ibu. Pusat Data dan Informasi Kementerian Kesehatan RI.

Maas, A. J. B. M., Vreeswijk, C. M. J. M., Braeken, J., Vingerhoets, A. J. J. M., \& van Bakel, H. J. A. (2014). Determinants of maternal fetal attachment in women from a community-based sample. Journal of Reproductive and Infant Psychology, 32(1), 5-24. https://doi.org/10.1080/02646838.2013.853170

Maimunah, A., \& Retnowati, S. (2011). Pengaruh pelatihan relaksasi dengan dzikir untuk mengatasi kecemasan ibu hamil pertama. Psikoislamika, 8, 1-22.

Mgawadere, F., Kana, T., \& van den Broek, N. (2017). Measuring maternal mortality: A systematic review of methods used to obtain estimates of the maternal mortality ratio (MMR) in low- and middleincome countries. British Medical Bulletin, 121(1), 121-134. https://doi.org/10.1093/bmb/ldw056

Navidpour, F., Dolatian, M., Yaghmaei, F., Majd, H. A., \& Hashemi, S. S. (2015). Examining Factor Structure and Validating the Persian Version of the Pregnancy's Worries and Stress Questionnaire for Pregnant Iranian Women. Global Journal of Health Science, 7(6), p308. https://doi.org/10.5539/gjhs.v7n6p308

Rahmawati, T. (2015). Hubungan dukungan suami dengan kejadian anemia pada ibu hamil di wilayah kelurahan sukatani kecamatan tapos kota depok. STIKes Jayakarta.

Rusanen, E., Lahikainen, A. R., Pölkki, P., Saarenpää-Heikkilä, O., \& Paavonen, E. J. (2018). The significance of supportive and undermining elements in the maternal representations of an unborn baby. Journal of Reproductive and Infant Psychology, 36(3), 261-275. https://doi.org/10.1080/02646838.2018.1462476

Schetter, C. D. (2011). Psychological Science on Pregnancy: Stress Processes, Biopsychosocial Models, and Emerging Research Issues. Annual Review of Psychology, 62(1), 531-558. https://doi.org/10.1146/annurev.psych.031809.130727

Schönfeld, P., Brailovskaia, J., Bieda, A., Zhang, X. C., \& Margraf, J. (2016). The effects of daily stress on positive and negative mental health: Mediation through self-efficacy. International Journal of Clinical and Health Psychology, 16(1), 1-10. https://doi.org/10.1016/j.ijchp.2015.08.005

Widodo, Y., Amanah, S., Pandjaitan, N. K., \& Susanto, D. (2017). Pengaruh faktor sosial ekonomi dan budaya terhadap perilaku persalinan di pedesaan daerah angka kematian ibu rendah dan tinggi. Indonesian Journal of Reproductive Health, 8(1), 77-88. https://doi.org/10.22435/kespro.v8i1.6753.77-88

Zhang, Y., \& Jin, S. (2016). The impact of social support on postpartum depression: The mediator role of $\begin{array}{lllll}\text { self-efficacy. Journal of Health } & \text { Psychology, }\end{array}$ https://doi.org/10.1177/1359105314536454 